\title{
Serve, Teach, and Lead: It's All about Relationships
}

\author{
Carolyn Crippen, PhD \\ Associate Professor, Department of Educational Psychology \\ University of Victoria, Canada
}

Once a person assumes the mantle of teacher, one becomes a leader, first, in the classroom and then in the school (Crippen, 2005). With this position comes a delicate power and responsibility to the moral imperative. As such, this issue is critical as a component of teacher preparation programs. Goodlad (2004) sounds the alarm that our teacher preparation programs are remiss in responding to the need for moral literacy in our schools. The following paper will introduce the philosophy of servant-leadership, a moral way of serving, as defined by Robert $K$. Greenleaf (1970/1991) and will respond to Goodlad's call with possibilities for preservice teachers that help them examine and define their role in contributing to the common good through servant-leadership.

A servant-leader is servant first. It begins with the natural feeling that one wants to serve. Then conscious choice brings one to aspire to lead. The difference manifests itself in the care taken by the servant- first, to make sure that other people's highest priority needs are being served. The best test is: do those served grow as persons; do they while being served, become healthier, wiser, freer, more autonomous, more likely themselves to become servants? And what of the least privileged in society: will they benefit, or at least, not be further deprived? (Greenleaf, 1970/1991, p. 7)

My experiences as a classroom teacher, principal, school superintendent, and education faculty member have provided me with a broad and privileged perspective on teacher education. Today there is an emphasis on the development of democratic learning environments within educational organizations where teacher-leaders reflect an authentic attitude in their professional behavior. Crippen (2005) writes that once you assume the mantle of teacher, you become a leader in your classroom and then in your school and learning community. Such leadership situations provide an opportunity to contribute to the moral ethos of that learning environment. Goodlad, Mantle-Bromley, \& Goodlad (2004) believe that school teaching and leadership are moral endeavors and that preservice teacher education programs seldom address the needs for moral leadership in democratic schools. Fullan (2003) reminds us, "One of the great

Teaching is all about making connections with people. It is about relationships and investment in others and their future and ours. strengths one needs, especially in troubled times, is a strong sense of moral purpose" (p. 19), and Sergiovanni (1992) echoes these values, with his idea, "Our goal should be to develop a leadership practice based on professional moral authority" (p. 29). Teaching is all about making connections with people. It is about relationships and investment in others and their future and ours. In terms of teacher preservice training and its relationship to students in the schools, we are reminded by Glickman, Gordon, \& Ross Gordon (2005) of our ultimate responsibility: "In a democratic society, it is vital that students learn to think reflectively, function at high stages of moral reasoning, and be autonomous decision makers" (p. 156). And, with these expectations of moral responsibility and deliberate steps toward school democratization, the leadership beliefs and values of 
those that aspire and enter the teaching profession become critical for faculties of education and teacher education programs to consider and to develop (Crippen, 2007; Goodman \& Balamore, 2003; Pajares, 1992). Only by carefully analyzing your beliefs and values can you model and help develop moral literacy (Herman, 2007; Tuana, 2007) with your students. Moral literacy involves a search for knowledge about moral issues; a development of moral reasoning; and the cultivation of moral virtues (Tuana. 2003). In fact, such personal reflection is critical for every teacher, regardless of how long they have been in the teaching profession. My question is: Where are you now (with your investment in the moral imperative)? The following paper is a response to the recognized need for moral leadership development in teacher education programs through the introduction of a philosophy of moral leadership, i.e., servant-leadership, which enables preservice teachers (and all teachers) to carefully deconstruct their value and belief systems and

\section{Personal reflection is critical for every teacher, regardless of how long they have been in the teaching profession.}

to examine their raison d'etre. Within the paper are suggestions for integration of moral literacy through reflective thought, careful listening, collaboration, lateralization of leadership, encouraging the growth of others, and the building of democratic communities. While servant-leadership contributes to the scholarship of teaching and learning excellence, it ultimately responds to the moral imperative and to concerns expressed by Goodlad et al., (2004).

\section{Background}

During the 1980s, as a classroom teacher and later as a consultant with the Carleton Board of Education (Ottawa, Ontario), I became acquainted with the writing of Robert Kiefner Greenleaf (1904-1990) and his philosophy of servantleadership. Greenleaf's ideas resonated with me. Greenleaf was interested in developing caring, collaborative, inclusive communities. He worked with business, industry, and educational institutions, particularly in the U.S. In 1970, at the age of sixty-six, Greenleaf wrote a 37-page essay, The Servant as Leader, which identified a way of serving and leading and following. He believed that in order for one to lead, one first had to want to serve others, not for profit or gain of any sort, but simply because one wanted to do so; it was an intrinsic feeling. That desire for service, and action, was the right thing to do. I would suggest that teachers often fall into this category of serving, leading, and following. Good leaders must also be good followers.

As our schools move toward a more democratic way of working, it seems logical that a positive mindset toward service, leadership, and followership in teacher education would be a starting point. Perhaps servant-leadership can provide the seeds for enabling preservice teachers to become effective, caring, moral leaders.

\section{Servant-Leadership}

The term "servant-leadership" was introduced by Greenleaf, as noted, in his first essay entitled, The Servant as Leader (1970/1991). He tells of discovering the concept of servant-leadership through reading Journey to the East by Herman Hesse, (1956/1992), the story of a band of men who set out on a long journey. Accompanying the men is a fellow named Leo whose job is to care for the band of men by doing all of the menial chores and providing for their comfort. The journey progresses well until Leo disappears. At this point, the men fall into disarray and the journey is aborted. 
Many years later, the narrator of the story encounters Leo and discovers that Leo's service is intrinsic and comes from his heart. But, Leo is actually the titular head of the organization that has sponsored the journey. Greenleaf saw in this story the message that one must first serve society, and through that service, regardless of position, a person will be recognized as a leader. There are servantleaders everywhere, but because they do not seek personal recognition, they often just go about their business in a quiet fashion. "Effective servant-leaders can be so subtle about it that all anybody is likely to see is the result. They don't see the cause" (Greenleaf, 2002, p.151).

Working with educational, business and industrial organizations, Greenleaf's goal was to develop strong, effective, caring communities in all segments of society - a goal that is consistent with a commitment to effective schools, but one that requires time in which to develop the necessary servantleader qualities. Goodlad (2004), who has been involved in studying preservice teacher education programs for many years, reminds us that "Students need to be involved with adults who care deeply for their well-being" (p. 127) and "They need to recognize and ultimately embrace the kind of humility that accompanies a willingness and preparedness to learn" (p. 127).

\section{Servant-Leader Characteristics}

Larry Spears (1998a), the former Executive Director of the Robert $K$. Greenleaf Center in Indianapolis, describes ten characteristics of servant-leadership found in Greenleaf's writing, and Barbuto and Wheeler from the University of Nebraska have identified an eleventh characteristic (Sipe \& Frick, 2009). These characteristics relate directly to teachers, classrooms, and learning communities. Let us look briefly at each of the eleven characteristics as it relates to teacher education programs. The first ten belong to Spears (1998a) and the eleventh to Barbuto \& Wheeler.

\section{Listening}

Effective educational leaders are great communicators and must be good listeners, to themselves (through their inner voice), as well as to others. This refers to a deep commitment to listen to others. Greenleaf states, "A true natural servant automatically responds to any problem by listening first" (Sipe \& Fink, 2009, p. 45). Proponents of the servant-leadership model emphasize the need for silence, reflection, meditation, active listening, and actually "hearing" both what is said and what is unsaid. The best communication forces you to listen (DePree, 1989). Sipe \& Frick (2009) carefully describe the active listening process:

Active listeners not only listen to the speaker's words, but also watch for and listen to the speaker's important nonverbal cuesbody language, gestures, facial expressions, tone of voice. Their body language demonstrates that they are paying careful attention to the speaker, choosing to be intimately involved with the speaker's experience at that very moment. Let's just call it, "being with". (p. 60)

I would call this being in the moment.

It is critical to preservice teachers that time is provided for them to examine their values and beliefs and classroom experiences carefully. If they do not do so, any change to their belief system and their practice is unlikely to occur. Such self-reflection can take the form of journaling or small group sharing. This is a worthwhile activity for all students and allows them to analyze their thought development over time. Also, during all interactions, i.e., student discussion, 
mentor-mentee sharing, case conferences, parent meetings, telephone conversations, etc., there is vigilant listening and "accurate" hearing in these conversations. Sergiovanni (1992) says that what students want more than anything else is to be listened to, and this seems to be the greatest investment all teachers can give students-their time. Often during seminars or university course sessions, I ask the students to tell, what did you hear in your group? They do not have to mention anyone by name, simply the information. Next, I ask if anyone from that group wishes to add information or clarify what was heard or said. This promotes careful reflection and seems to help intensify the quality of listening within the university classroom. By the end of the course, the responses are lengthier, more articulate and detailed in substance.

\section{Empathy}

A good servant-leader strives to understand and empathize with others. But this understanding should be supportive as opposed to patronizing; "It is a misuse of our power (as leaders) to take responsibility for solving problems that belong to others" (Block, 1993/1996, p. 7). Compassion and empathy can help develop a positive home-school relationship. Parents appreciate a caring and sensitive attitude from all school personnel, especially their child's

\section{A good servant-leader strives to understand and empathize with others.} teacher. Preservice teachers need time to develop such skills and to gain confidence in interacting with school stakeholders. Most preservice teachers are in survival mode (Naested, Potvin, \& Waldron, 2004), going day to day, as they learn and grow in their profession. I would suggest that all recent graduates are trying to keep their heads above water in any new job or situation. Teacher education faculty members and preservice teachers may gain valuable insight from Greenleaf's comments explaining the relationship between empathy and the development of trust. Individuals grow taller when those who lead them empathize and when they are accepted for what they are, even though their performance may be judged critically in terms of what they are capable of doing. Leaders who empathize and who fully accept those who go with them on this basis are more likely to be trusted (Spears, 1998a, p.81).

Healing

Servant-leaders have the potential to heal both themselves and others. A happy, positive school environment, where staff, students, and parents feel welcome, creates a sense of wellness. Healthy leaders cannot always find followers. Sturnick (1998) states, "sick organizations really do contaminate" (p. 191). Sergiovanni (1992) mentions that there are many students in pain in our schools, and a kind, caring word from a teacher can make the difference in their day. Many preservice teachers who not long ago were students in the K-12 school system can relate easily to the students in the classroom. Over the years, I have found preservice teachers anxious to understand issues such as suicide, death, drug addiction, sexual abuse, physical violence, poverty, and other crises. When they return from their first placement in the field, the questions around these topics surface. Teacher education programs must respond to these legitimate concerns by bringing in experts in these areas or by integrating such topics into the educational psychology course offerings. 
Servant-leaders develop general awareness, especially self-awareness, through self-reflection, by listening to what others say about them, by being continually open to learning, and by making the connection between what they know and believe and what they say or do. "Awareness also aids one in understanding issues involving ethics and values. It lends itself to being able to view most situations from a more integrated, holistic position" (Spears, 1998b, p. 6). An opportunity for dialogue about educational practice is critical in dealing with the needs of preservice teachers. Effective and supportive programs require ongoing checks that provide opportunity for revisions or redirection when needed. Professional development, guest speakers, study groups, peer discussions, and committee meetings permit preservice teachers to observe and absorb ideas from their colleagues. Importantly, for all educators, we must become students of our students. We must observe and listen carefully to our students so that we may come to know them and to establish a caring relationship with them. These actions help preservice teachers develop awareness.

Persuasion

The servant-leader seeks to convince others, rather than coerce compliance. Coercion involves an abuse of power. Servant-leaders are willing to take the time for consensus building through a sharing of power within the group. Everyone has voice. Greenleaf explains persuasion,

One is persuaded upon arriving at a feeling of rightness about a belief or action through one's own intuitive sense, persuasion is usually too undramatic to be newsworthy... Significant instances of persuasion may be known to only one or a few, and they are rarely noted in history. Simply put, consensus is a method of using persuasion in a group. (Frick \& Spears, 1996, p. 139-140)

We are all just a mess of stories and we must tell and share these stories with each other. "Stories encode the values of a person and an organization" (Sipe \& Frick, 2009, p. 75), and "If you want to shape a servant-led culture, begin by telling stories of serving that inform, entertain and, most of all, inspire" (p. 75). Goodlad (2005) explains the results of Howard Gardner's (1995) research into persuasive direct leaders (I would include preservice teachers as direct leaders): ... Jive their lives in accordance with their stories. In other words, they need to lead by example. Such leaders model and embody the values and behaviors they are trying to instill in others, whether such values and behaviors are, for instance, open inquiry, risk taking, or simply valuing life as a learning process. (p. 133)

When preservice teachers return to the university after being on practicum, I always use the first class we are back together to debrief and to tell our stories. In my experience, these sessions are always high energy, exciting, intense, and continue until the last minute of class.

\section{Conceptualization}

Servant-leaders seek to nurture their own abilities to dream great dreams. Greenleaf (cited in Frick \& Spears, 1996) describes conceptual talent as:

The ability to see the whole in the perspective of history-past and future-to state and adjust goals, to evaluate, to analyze, and to foresee contingencies a long way ahead. Leadership, in the sense of going out ahead to show the way, is more conceptual than 
operating. The conceptualizer, at his or her best, is a persuader and a relation builder. (p. 217)

I would suggest that conceptualization is "having a big-picture perspective." Preservice teachers are immersed into a school curriculum that has deadlines for reporting and timelines for assignments and bells to control the beginning and ending to the school day. Being able to conceptualize the lesson, the day, and the week becomes paramount to their ability to succeed in the school setting. One must look beyond the day-to-day (immediate) realities of the classroom to the long-term repercussions of learning needs (Spears, 1998b). Considerable practice over time will fine-tune this ability.

\section{Foresight}

Greenleaf refers to this ability to foresee or know the likely outcome of a situation as a better-than-average guess about "what" is going to happen "when", in the future. Experience plays the greatest part in the preservice teacher development of foresight when working with students in the classroom and answering questions such as: How can a student be accommodated in a sensible and realistic way? What barriers could exist to prevent success? What necessary supports must be in place? Greenleaf (1991) says foresight is "the lead that a leader has" and goes on to state:

Foresight means regarding the events of the instant moment and constantly comparing them with a series of projections made in the past and at the same time projecting future events-with diminishing certainty as projected time runs out into the indefinite future. (p.18)

I believe preservice teachers develop considerable foresight as they progress through teacher preparation programs. Their foresight relates to their prior experience in working with children, especially in structured situations, i.e., teaching dance or piano lessons; working as a hockey coach; leading a camping group. At the conclusion of several classes each term, I require a one-minute paper from my preservice teachers. The topic is: What did I learn today? This brief assignment provides metacognition for the preservice teacher; it also delivers valuable information to the instructor, i.e., issues of concern, future direction, pacing, strengths and challenges of particular topics.

\section{Stewardship}

Greenleaf believed all members of an institution or organization play significant roles in caring for the well-being of the institution and serving the needs of others in the institution, for the greater good of society. Sergiovanni (1992) explains that stewardship “involves the leader's personal responsibility to manage her or his life and affairs with proper regard for the rights of other people and for the common welfare" (p. 139). Effective schools provide an environment for the common good of all students, regardless of their particular needs. Preservice teachers might take

Effective schools provide an environment for the common good of all students, regardless of their particular needs. counsel from Wheatley (2006), “...if we hear our colleagues speak about their own yearnings to make a small difference, we feel new energy for the work and for each other. The call of meaning is unlike any other" (p. 133). Servant-leaders simply do because it is right, a moral obligation. 


\section{Commitment to the growth of others}

Servant-leaders are committed to the individual growth of human beings and will do everything they can to nurture others. DePree (1989) writes: "The signs of outstanding leadership appear primarily among the followers. Are the followers reaching their potential? Are they learning? Serving?" (p. 12). Johnston (2006) is clear in her support for learning about moral responsibility: "I believe that in both pre- and in-service education, we must include multiple conversations about what is moral and how what is moral fits into public education" (p. 59). The purpose of our schools is simply the promotion of the growth of others. But Fullan (2005) is more specific; he identifies three areas of growth in schools: academic, personal, and social. Ultimately, the goal for all those involved in education programs should be the development of positive, participating citizens. "Ask yourself what are three things I can do this week to hold myself accountable for the growth of others?" (Sipe \& Frick, 2009, p. 172). Greenleaf (1977) speaks directly to all teachers: Many teachers have sufficient latitude in dealing with students that they could, on their own, help nurture the servant leader potential, which I believe, is latent to some degree in almost every young person. Could not many respected teachers speak those few words that might change the course of life, or give it new purpose? (p. 5)

\section{Building community}

The servant-leader seeks to identify some means for building community. "Community means acknowledging that we are in a relationship with one another" (Johnston, 2006, p. 73). Wheatley (2006) adds, "We are constantly called to be in relationship-to information, people, events, ideas, life" (p. 145). Sergiovanni (1994) adds the importance of caring as "an integral part of shared community" ( $p$. 146). And additional words from Margaret Wheatley (2007) stress the importance of relationships: "And people learn best in community, when they are engaged with one another, when everyone is both student and teacher, expert and apprentice, in a rich exchange of experiences and learning" (p. 173). We want all our children to feel wanted and treated as valuable, capable, and responsible within the school community (Crippen, 2005).

\section{Calling}

A servant-leader wants to make a difference for others and to have an impact on their lives. They will sacrifice their own self-interests for the sake of others. They choose "to lead as a servant, to risk mistakes and achievements" (Sipe \& Frick, 2009, p. 37). Fullan (2005) asks directly what is motivating you to make a difference. Preservice teachers might ponder this question. One of the standard questions directed toward preservice teachers in class or during intake interviews into the teacher education program is: Why did you want to become a teacher? Responses frequently contain references to a calling, a wanting to make a difference, to being a part of the moral imperative. Digging more deeply into this question through whole class discussion may prove enlightening to faculty and preservice teachers. Why do they think they have such a calling? How was this call to service nourished in their lives? Could any of what they learn from the discussion be transferred into their own future classrooms? 


\section{Conclusion}

In 1997 the concept of servant-leadership was introduced to educators in central Manitoba at the Parkland Leadership Academy. Over the past seven years, well over 1200 people in Manitoba have learned and /or studied the writings of Greenleaf and his philosophy of servant-leadership. But Greenleaf (cited in Frick \& Spears, 1996) comments candidly to those involved in all types of organizations about the importance of servant-leaders:

This is not a bandwagon idea; it is not a best-seller kind of thing; but nevertheless, these people (servant-leaders) do exist, and some of them have become very important to me. (p. 343)

And,

The difference between organizations is how people relate and how they actually function, which may not bear a whole lot of relationship to how the thing is sketched out on paper. (p. 347)

The Manitoba Association of School Trustees (MAST) brought servantleadership to the attention of over 400 trustees at their annual fall conference (2002). During summer 2003, the annual Canadian School Board Association Congress was held in Winnipeg, and two sessions were presented on ServantLeadership to sixty trustees and superintendents from across Canada.

In addition, several education courses at the University of Manitoba, Faculty of Education, included books by Greenleaf as part of required readings, reflection, and analysis in undergraduate, post baccalaureate, and graduate courses. These university courses have been repeated several times. A ServantLeadership Course has been added to the Education graduate course offerings at the University of Victoria. It has run twice to capacity classes. An entire school district in Victoria focused the keynote for their professional development day on servant-leadership and added two additional workshops (one for elementary and one for secondary teachers). As this paper was being written, two students are involved in independent research that connects servant-leadership to the university campus and to the community at large. Networks of teachers and administrators are proposing Greenleaf study groups; three novice teachers have applied successfully for funding to initiate in-depth, long- term implementation of the Greenleaf philosophy into their middle schools. Their kick-off evening was well-attended and supported the making of webs of relations. Wheatley (2006) speaks wisely to all educators across faculties:

Most of us have had the experience of touching a spider web,

feeling its resiliency, noticing how slight pressure in one area jiggles the entire web. If a web breaks and needs repair, the spider doesn't cut out a piece, terminate it, or tear the entire web apart and reorganize it. She reweaves it, using the silken relationships that are already there, creating stronger connections across the weakened spaces. (p. 145)

It seems to me that it is an honor and a privilege to stand before a class of students. At the same time, there is a heavy moral responsibility to contribute to the moral imperative. The servant-leadership paradigm is one way to create a strong foundation for moral literacy and caring learning communities among all post secondary faculty in our colleges and universities. Servant-leadership situates itself comfortably within the scholarship of teaching and learning as well as serving and leading. And, it also responds to Goodlad's concerns for attention to moral leadership in teacher education programs. Servant-leadership is real and the ripple effect has begun. Where are you now in contributing to that moral endeavor? 


\section{References}

Block, P. (1993/1996). Stewardship: Choosing service over self-interest. San Francisco, CA: Berrett-Koehler Publishers.

Crippen, C. (December 5, 2005). The democratic school: First to serve, then to lead. The Canadian Journal of Educational Administration and Policy, Issue 47.

Crippen, C. (2007). Teachercandidate perceptions of educational leadership. Democratization in Manitoba schools. WestCAST Conference 2007. Winnipeg, MB: University of Manitoba.

DePree, M. (1989). Leadership is an art. New York, NY: Dell Publishing Group.

Frick, D. \& Spears, L. (Eds.). (1996). The private writing of Robert $K$. Greenleaf: On becoming a servant leader. San Francisco. CA: J osseyBass.

Fullan, M. (2003). The moral imperative of school leadership. CA: Corwin Press.

Gabriel, J. (2005). How to thrive as a teacher leader. Alexandria, VA: Association for Supervision and Curriculum Development.

Glickman, C., Gordon, S., \& Ross Gordon, J. (2005). The basic guide to supervision and instructional leadership. Toronto, ON: Pearson Education.

Goodlad, J., Soder, R., \& Sirotnik. (Eds.). (1990). The moral dimension of teaching. San Francisco, CA: Jossey-Bass.

Goodlad, J., Mantle-Bromley, C., \& Goodlad, S. (2004). Education for everyone: Agenda for education in a democracy. San Francisco, CA: J ossey-Bass.
Goodman, J. \& Balamore, U. (2003). Teaching goodness: Engaging the moral and academic promise of young children. Toronto, ON: Pearson Education Canada.

Greenleaf, R. (1977). Servant leadership. Mahwah, NJ: Paulist Press.

Greenleaf, R. (1991). Advice to servants. Indianapolis, IN: Robert K. Greenleaf Center.

Greenleaf, R. (2002). Teacher as servant: A parable. Indianapolis, IN: Robert K. Greenleaf Center.

Greenleaf, R. (1970/1991). The servant as leader. Indianapolis, I N: Robert K. Greenleaf Center.

Herman, B. (2007). Moral literacy. Cambridge, MA: Harvard University Press.

Hesse, H. (1956/1992). Journey to the east. New York, NY: Noonday Press.

Johnston, D. (2006). Education for a changing society: Classroom relationships and moral action. New York, NY: Teachers College Press.

Naested, I., Potvin, B., \& Waldron, P. (2004). Understanding the landscape of teaching. Toronto, ON: Pearson Publishing

Pajares, F. (Fall, 1992). Teacher beliefs and educational research: Cleaning up a messy construct. Review of Educational Research.

Sergiovanni, T. (1992). Moral leadership. San Francisco, CA: Jossey-Bass.

Sergiovanni, T. (1994). Building community in schools. San Francisco, CA: J ossey-Bass.

Sipe, J. \& Frick, D. (2009). Seven pillars of servant leadership: Practicing the wisdom of leading by serving. Mahwah, NJ : Paulist Press. 
Spears, L. (Ed.). (1998a). Insights on leadership: Service, stewardship, spirit and servant-leadership.

Toronto, ON: John Wiley \& Sons, Inc.

Spears, L. (Ed.). (1998b). Robert K. Greenleaf: The power of servant leadership. San Francisco, CA: Berrett-Koehler Publishers, Inc.

Sturnick, J. (1998). Healing leadership. In L Spears. (Ed.) Insights on leadership: Service, stewardship, spirit and servantleadership. Toronto, ON: John Wiley \& Sons, Inc.

Tuana, N. (2007). Conceptualizing moral literacy. Journal of Educational Administration, 45 (4) 364-378.
Tuana, N. (May, 2003). Moral literacy. Penn State On-Line Research, 24(2). Retrieved from www.ed.psu.edu/educ/pssc/publicati ons/Moral\% 20Literacy\% 20Beacon $\% 2$ 0in\%20Publisher_\%20V3\%.

Wheatley, M. (2007). Finding our way: Leadership for an uncertain time. Berkeley, CA: Berrett-Koehler Publ., Inc.

Wheatley, M. (2006). Leadership and the new science: Discovering order in a chaotic world. $3^{\text {rd }}$ ed. San

Francisco, CA: Berrett-Koehler Publishers, Inc.

Carolyn Crippen (BA-Carleton, MEd-Ottawa, PhD- North Dakota) is Associate Professor of Leadership Studies in the Faculty of Education, University of Victoria, British Columbia, Canada. She was the former Assistant Dean of Education at the University of Manitoba. Prior to entering the academy, she had a lengthy career in the public school systems as teacher, principal, consultant, and school superintendent. Carolyn's areas of research include servant-leadership, teacher education, and school administration. Carolyn has published widely and presented nationally and internationally, most recently in Switzerland and Iceland. 